\title{
Epidemiology of Basil Downy Mildew
}

\author{
Yigal Cohen, ${ }^{\dagger}$ Yariv Ben Naim, Lidan Falach, and Avia E. Rubin
}

Faculty of Life Sciences, Bar Ilan University, Ramat Gan, Israel.

Accepted for publication 16 April 2017.

\begin{abstract}
Basil downy mildew (BDM) caused by the oomycete Peronospora belbahrii is a destructive disease of sweet basil (Ocimum basilicum) worldwide. It originated in Uganda in the 1930s and recently spread to Europe, the Middle East, Americas, and the Far East. Seed transmission may be responsible for its quick global spread. The pathogen attacks leaf blades, producing chlorotic lesions with ample dark asexual spores on the lower leaf surface. Oospores may form in the mesophyll of infected leaves. The asexual spores germinate on a wet leaf surface within $2 \mathrm{~h}$ and penetrate into the epidermis within $4 \mathrm{~h}$. Spore germination and infection occur at a wide range of temperatures from 5 to $28.5^{\circ} \mathrm{C}$. Infection intensity depends on the length of dew period, leaf temperature, and inoculum dose. The duration of latent period (from infection to sporulation) extends from 5 to 10 days, depending on temperature and light regime. The shortest is 5 days at $25^{\circ} \mathrm{C}$ under continuous light. Sporulation requires high humidity but not free leaf wetness. Sporulation occurs at 10 to $26^{\circ} \mathrm{C}$. At the optimum temperature of $18^{\circ} \mathrm{C}$, the process of sporulation requires $7.5 \mathrm{~h}$ at relative humidity $\geq 85 \%$, with $3 \mathrm{~h}$ for sporophores emergence from stomata and $4.5 \mathrm{~h}$ for spore formation. Sporophores can emerge under light or darkness, but spore formation occurs in the dark only.

Limited data are available on spore dispersal. Spores dispersed from sporulating plants contaminate healthy plants within $2 \mathrm{~h}$ of exposure. Settled spores may survive on leaf surface of healthy plants for prolonged periods, depending on temperature. Seed transmission of the disease occurs in Europe, but not in Israel or the United States. P. belbahrii in Israel also attacks species belonging to Rosemarinus, Nepeta, Agastache, Micromeria, and Salvia but not Plectranthus (coleus). A Peronospora species that infects coleus does not infect sweet basil. Control of BDM includes chemical, physical, and genetic means. The fungicide mefenoxam was highly effective in controlling the disease but resistant populations were quickly selected for in Israel and Europe rendering it ineffective. A new compound oxathiapiprolin (OSBP inhibitor) is highly effective. Nocturnal illumination of basil crops controls the disease by preventing sporulation. Daytime solar heating suppressed the disease effectively by reducing spore and mycelium viability. The most effective physical means is fanning. Nocturnal fanning prevents or limits dew deposition on leaf surfaces, and as a result, infection and sporulation diminish and epidemics are prevented. Genetic resistance occurs in wild basil and its transfer to sweet basil is under way.
\end{abstract}

Basil downy mildew (BDM) caused by the oomycete Peronospora belbahrii is one of the most destructive diseases of sweet basil. It was first reported in Uganda in 1932 as Peronospora spp. and again in 1937 as $P$. lamii, causing defoliation and death of sweet basil (Belbahri et al. 2005; Hansford 1933). The disease emerged in Switzerland in 2001 (Belbahri et al. 2005). Subsequent occurrence of the disease was reported as follows: Italy in 2003 (Garibaldi et al. 2004a), France and Belgium in 2004 (Coosemans 2004; Garibaldi et al. 2005), South Africa and Malta in 2005 (McLeod et al. 2006; Porta-Puglia and Mifsud 2006), Iran in 2006 (Khateri et al. 2007), Cameroon (Voglmayr and Piatek 2008) and the United States in 2007 (and then, in various U.S. states: Babadoost 2010; Blomquist et al. 2009; McGrath et al. 2010a; McGrath et al. 2010b; Raid et al. 2010; Roberts et al. 2009; Westerveld et al. 2015; Wick and Brazee 2009), Argentina in 2008 (Ronco et al. 2008), Taiwan in 2009 (Chen et al. 2010), Hungary and Cuba in 2010 (Martinez de la Parte et al. 2010; Nagy and Horvath 2011), Israel and Canada in 2011 (Cohen et al. 2013b; Saude et al. 2013), Czech Republic in 2012 (Petrzelova et al. 2015; Safrankova and Holkova 2014), U.K., Cyprus, and China in 2014 (Denton et al. 2015; Kanetis et al. 2014; Kong et al. 2015), and Mexico and Korea in 2015 (Bastidas et al. 2016; Choi et al. 2016). In the U.K., P. belbahrii was found on coleus in 2010 (Henricot et al. 2010). Currently, BDM occurs in all parts of the world where sweet basil is grown.

†Corresponding author: Y. Cohen; E-mail address: Yigal.cohen1@gmail.com

This article is in the public domain and not copyrightable. It may be freely reprinted with customary crediting of the source. The American Phytopathological Society, 2017.

\section{THE PATHOGEN AND ITS HOSTS}

$P$. belbahrii is an obligate oomycete pathogen attacking mainly sweet basil (Ocimum basilicum, Labiaceae). The causal agent produces chlorotic lesions on leaf blades with ample spores developing on the lower and upper leaf surfaces (Fig. 1A and B). Lesions gradually turn necrotic and infected leaves abscise. Spores are dark purple, oval, $30.4 \pm 2.9 \mu \mathrm{m}$ long $\times 21.4 \pm 1.7 \mu \mathrm{m}$ wide (Cohen et al. 2013a) (Fig. 2A and B). Sporophores, emerging from stomatal openings in a saturated atmosphere, are hyaline, 400 to $600 \mu \mathrm{m}$ long, dichotomously branched, with three to five branches per sporophore, and bear a single spore on each branchlet tip (Cohen et al. 2013a). Infected plants (symptomless or not) are disqualified for marketing. Symptomless infections may pop up during marketing as dark lesions.

Coleus (Plectranthus scutellarioides) and Agastache spp. have been reported as hosts of $P$. belbahrii (Choi et al. 2009; Denton et al. 2015; Farr and Rossman 2015; Henricot et al. 2010; Rivera et al. 2016; Thines et al. 2009; Vu et al. 2013). In Israel, isolates of $P$. belbahrii from sweet basil (Fig. 1A and B) do not infect coleus but do infect and sporulate on the following species of Labiaceae: rosemary (Rosmarinus officinalis) (Fig. 1C) Nepeta (Nepeta curviflora), Clinopodium (Micromeria fruticosa), and two species of sage (Salvia pinnata and S. fruticosa) (Fig. 1D). Spores collected from these plant species were infective to sweet basil. The role of these species in the epidemiology of BDM in Israel is unknown.

An unidentified species of Peronospora infects coleus (Plectranthus) in Israel (Fig. 1E to F). Spores of this species failed to infect sweet basil. A similar finding was reported from the United States by Harlan et al. (2015). Rivera et al. (2016) claimed that downy mildew on coleus in Tennessee is caused by $P$. belbahrii sensu lato. 


\section{ASEXUAL LIFE CYCLE}

Spore germination and infection. Spores of $P$. belbahrii require incubation of $\geq 2 \mathrm{~h}$ in water at 15 to $20^{\circ} \mathrm{C}$ to germinate (Cohen and Ben Naim 2016). They germinate with a single germ tube (Fig. 2C to F). Spores collected from frozen infected leaves (3 months at $-20^{\circ} \mathrm{C}$ or 2 years at $-80^{\circ} \mathrm{C}$ ) retain high germination capacity. Fresh and frozen spores were shown to germinate on water agar at 5 to $25^{\circ} \mathrm{C}$ (Djalali Farahani-Kofoet et al. 2014). Basil plants exposed to spore showers (in the field or in growth chambers) produced infection only if kept wet after inoculation. Garibaldi et al. (2007) reported that at least $6 \mathrm{~h}$ of leaf wetness are required for infection. Cohen and Ben Naim (2016) showed that free leaf moisture of $\geq 4 \mathrm{~h}$ at 15 to $20^{\circ} \mathrm{C}$ allowed infection. The germ tube produces an appressorium (Fig. 2D) and penetrates the leaf epidermis of intact plants directly into the periclinal cell wall (Fig. 2D), in between the anticlinal cell walls (Fig. 2E), or via the stomatal opening (Fig. 2F). Koroch et al. (2013) reported on stomatal penetration.

Cohen and Ben Naim (2016) studied the effect of dew period duration on infection in intact plants. Slight infection occurred at $4 \mathrm{~h}$ of dew period at $15^{\circ} \mathrm{C}$ in the dark; it increased significantly at $5 \mathrm{~h}$ and reached near maximum at $6 \mathrm{~h}$. Only slightly more infection occurred with 7 to $9 \mathrm{~h}$ of dew period. A 10-min interrupting dry period at 3 or $4 \mathrm{~h}$ postinoculation had a strong negative impact on infection probably because germ tubes were at their critical stage of penetration.
Studying the effect of dew period duration and inoculum dose (in the dark at $15^{\circ} \mathrm{C}$ ) on infection showed that at $2 \mathrm{~h}$ no infection occurred, regardless of the inoculum dose used. At $4 \mathrm{~h}$, infection occurred with $\geq 300$ spores $/ \mathrm{ml}$, whereas at $\geq 6 \mathrm{~h}$ infection occurred at all spore doses, from 30 to 30,000 spores/ml (Cohen and Ben Naim 2016).

Temperature during the infection process has a profound impact on infection. In darkness, with inoculum dose of 5,000 spores $/ \mathrm{ml}$, the minimal and maximal temperature for infection of intact plants was 5 and $28.5^{\circ} \mathrm{C}$, respectively. The optimal temperature for infection depends on the duration of dew period. At $4 \mathrm{~h}$ of dew, infection occurs at 11.5 to $24.5^{\circ} \mathrm{C}$, whereas at 8 to $12 \mathrm{~h}$ dew period infection occurs at 7.5 to $24.5^{\circ} \mathrm{C}$. Infection reaches its maximal level at 11.5 to $15.5^{\circ} \mathrm{C}$ with $8 \mathrm{~h}$ of dew period. With 50,000 spores/ $\mathrm{ml}$ and a dew period of $8 \mathrm{~h}$, trace infection occurred at the marginal temperatures of 5 and $28.5^{\circ} \mathrm{C}$ (unpublished data). No information is available on the effect of light on infection.

Djalali Farahani-Kofoet et al. (2014) studied the effect of inoculum density on infection. They inoculated four-leaf potted basil plants with 3,000, 30,000, and 300,000 spores/ml and incubated the plants in the dark at $20^{\circ} \mathrm{C}$ for $24 \mathrm{~h}$, and then at 18/ $23^{\circ} \mathrm{C}$ with $12 \mathrm{~h}$ light/day. At 14 days postinoculation (dpi), disease severity was about the same for all inoculum doses: 88,94 , and $87 \%$, respectively, suggesting that with $24 \mathrm{~h}$ of wet period, inoculum density has no effect on infection intensity.

In brief, spore germination and penetration require free moisture. Ten minutes of dryness applied to inoculated leaves before fungal penetration hamper infection. At optimal temperature, infection
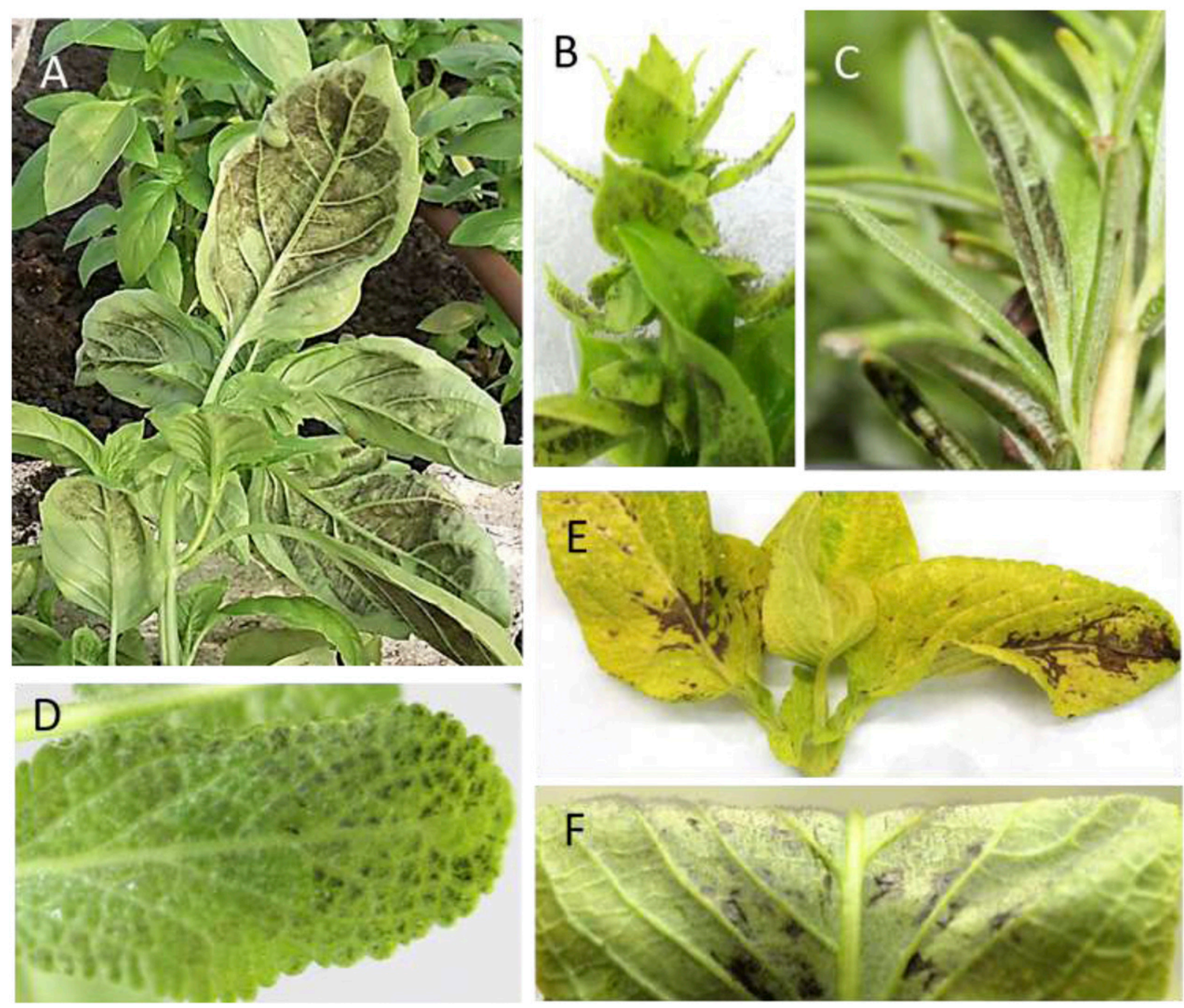

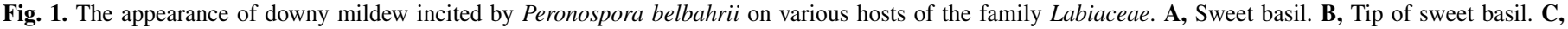

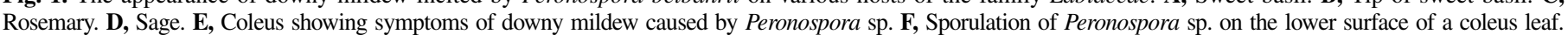


occurs in $4 \mathrm{~h}$. Increasing the inoculum dose and/or lengthening the dew period, widen the temperature range for infection. As shown below, fanning avoids dew deposition on basil crops, thereby suppressing BDM development in nature.

\section{COLONIZATION}

The degree of mycelium colonization of $P$. belbahrii inside basil leaves was determined by measuring the capacity of the pathogen to sporulate on infected leaves under standard conditions $(20 \mathrm{~h}, 100 \%$ relative humidity $[\mathrm{RH}], 18^{\circ} \mathrm{C}$, darkness). Temperature and light were major environmental factors affecting colonization of BDM. The minimal, optimal, and maximal temperature for colonization at $12 \mathrm{~h}$ photoperiod was $8.5,20$ to 25 , and $30^{\circ} \mathrm{C}$, respectively. The optimal day temperature for colonization was 25,20 to 25 , and 20 to $25^{\circ} \mathrm{C}$ at night temperature of 10,15 , and $20^{\circ} \mathrm{C}$, respectively. At all night temperatures, no colonization occurred at day temperature of 30 or $35^{\circ} \mathrm{C}$. A recovery period of 2 days at $25 / 25^{\circ} \mathrm{C}$ allowed resumption of the colonization in plants previously incubated at $13 / 30^{\circ} \mathrm{C}$ but not in those incubated at $13 / 35^{\circ} \mathrm{C}$ (unpublished data).

Onset of the disease in the field depended on the availability of inoculum (proximity to infected plants), leaf wetness duration, and temperature. Isolated crops remained disease-free for about 50 days, until first harvest. When infected plants were introduced into a healthy untreated crop during spring (mean temperature $\pm \mathrm{SD}$; $\left.26.1 \pm 5.6^{\circ} \mathrm{C}\right)$, summer $\left(28.4 \pm 4.8^{\circ} \mathrm{C}\right)$, or autumn $\left(26.7 \pm 5.5^{\circ} \mathrm{C}\right.$ ), disease showed up after 9 to 10 days. In winter crops grown in plastic-covered houses (mean temperature $18 \pm 8^{\circ} \mathrm{C}$ ), disease appeared after 14 days (unpublished data), indicating that inoculum availability is a major factor affecting break outs of the disease.
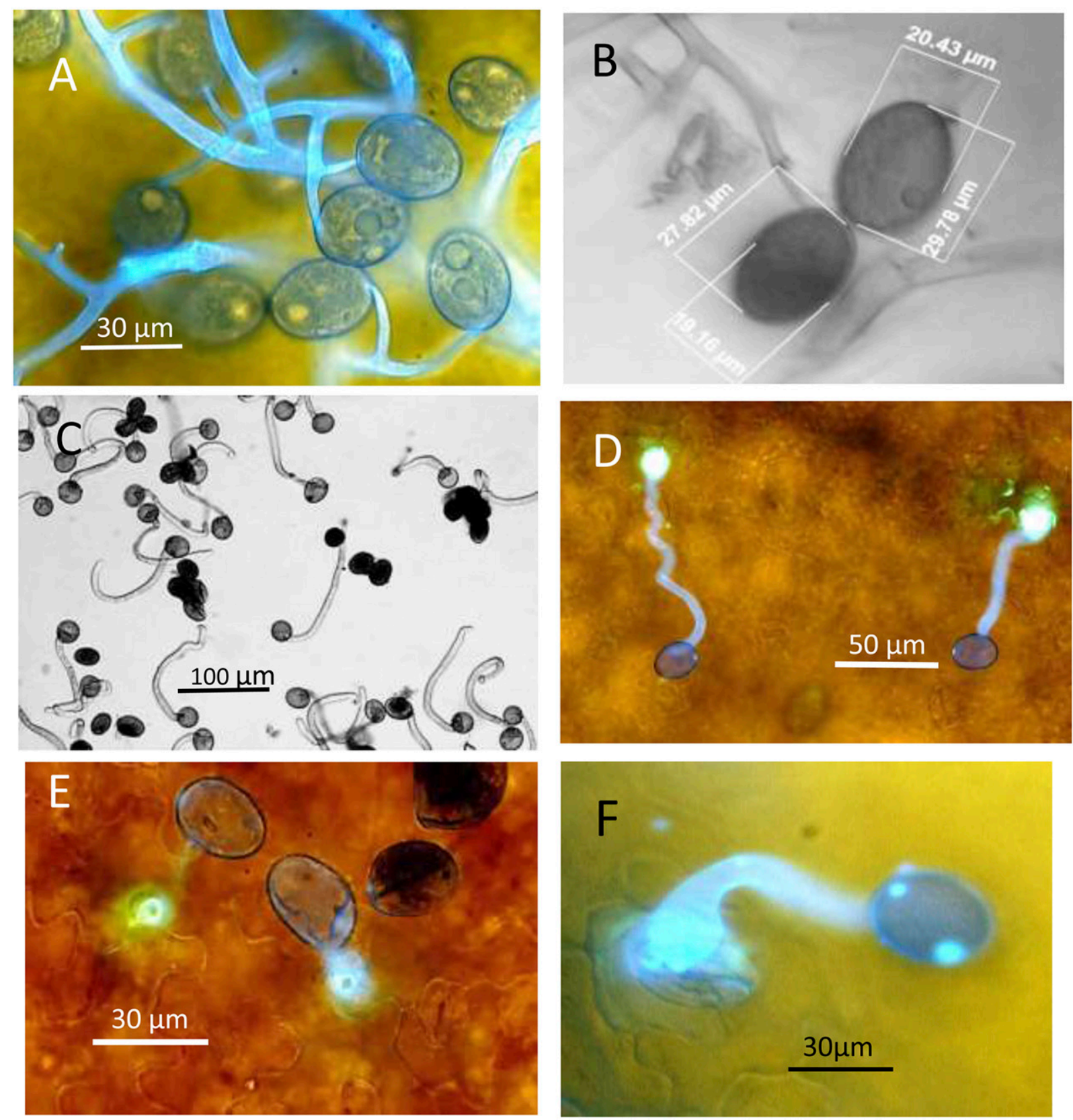

Fig. 2. Asexual spores of Peronospora belbahrii, their germination and penetration. A, Spores borne on their sporophores attached to the surface of sweet basil leaf. $\mathbf{B}$, Close up of attached spores with their size shown. C, Spores germinating in water after $2 \mathrm{~h}$ at $20^{\circ} \mathrm{C}$. D, Spore germination, appressorium formation, and penetration through the periclinal epidermis wall of a basil leaf. E, Penetration in between anticlinal cell walls of the epidermis. F, Penetration via the stomatal opening of a sweet basil leaf. Photos A, D, E, and F were taken with the aid of an epifluorescence microscope after staining with basic aniline blue and calcofluor. This technique was also employed with the other colored micrographs. 
Photoperiod affected colonization intensity. At a constant temperature of $25^{\circ} \mathrm{C}$, a longer photoperiod resulted in increased colonization (unpublished data). Incubation of infected plants under continuous illumination resulted with the fastest (latent period of 5 days) and greatest colonization (spore yield of $\sim 150 \times 10^{3} / \mathrm{cm}^{2}$ ) (Cohen and Ben-Naim 2016). Microscopic observations revealed no more than one haustorium (arrow) in a mesophyll cell (Fig. 3C).

\section{SPORULATION}

Unlike infection, sporulation does not require free leaf moisture. Garibaldi et al. (2007) reported that leaf wetness of at least $24 \mathrm{~h}$ after symptom appearance is necessary for sporulation. We showed that the number of spores produced on detached infected basil leaves increased as the surrounding RH increased. Spore production was equally high at RH $100 \%$ and RH $97.6 \%$, but significantly lower at RH $94.60 \%$ and almost nullified at RH $85.0 \%$ (Cohen and Ben-Naim 2016).

Microscopic observations during sporulation in a dew chamber in the dark at $18^{\circ} \mathrm{C}$ showed the following: at about $3 \mathrm{~h}$, white sporophores start emerging from the stomatal openings on the lower leaf surface; at 4 to $5 \mathrm{~h}$, the sporophores branched once or twice; at $6 \mathrm{~h}$, the sporophores branched thrice; at 7.5 to $8 \mathrm{~h}$, spores developed on the branchlet's tips; and at 11 to $14 \mathrm{~h}$, sporulation reached its final stage with maximal number of spores produced. Spore production increased with lengthening dew period duration. Thus, the number of spores produced per unit leaf area at $18^{\circ} \mathrm{C}$ in the dark was $0,0,41$, 83,142 , and $141 \times 10^{3} / \mathrm{cm}^{2}$ after a dew period of $4,6,7.5,8,11$, and $14 \mathrm{~h}$, respectively (Cohen and Ben-Naim 2016).

The effect of temperature on sporulation depends on the dew period duration. In plants kept at RH $100 \%$ for $9 \mathrm{~h}$, sporulation occurred at 10 to $20^{\circ} \mathrm{C}$. When the moist period was extended to $16 \mathrm{~h}$, sporulation occurred at 10 to $26^{\circ} \mathrm{C}$. No sporulation occurred at 5 or $28^{\circ} \mathrm{C}$ (unpublished data).

Under field conditions in Israel, sporulation occurred on dewy nights only. Profuse sporulation occurs in the spring and summer seasons when night temperatures ranged between 15 to $22^{\circ} \mathrm{C}$. Weak to moderate sporulation occurred in the winter season when night temperature fell from 8 to $10^{\circ} \mathrm{C}$ (unpublished data).

Interrupting the dew period during sporulation with a 10-min dry session greatly reduced spore production, more so in plants kept in a dew chamber for $9 \mathrm{~h}$ than in plants kept in a dew chamber for $24 \mathrm{~h}$. Infected basil plants placed in a dew chamber for $9 \mathrm{~h}$ showed sporulation on $\sim 73 \%$ of their leaf area; similar plants that were dried up for $10 \mathrm{~min}$ at $2 \mathrm{~h}$ after onset of dew showed sporulation on $35 \%$ of their leaf area and those dried at $3,4,5$, or $6 \mathrm{~h}$ showed no sporulation. When the total dew period has extended to $24 \mathrm{~h}$, percent leaf area sporulating in control plants was $81 \%$ and in plants interrupted at $2,3,4,5$, and $6 \mathrm{~h}$ was $69,59,30,0$, and $0 \%$, respectively. The data suggest that the sporophores that emerged at
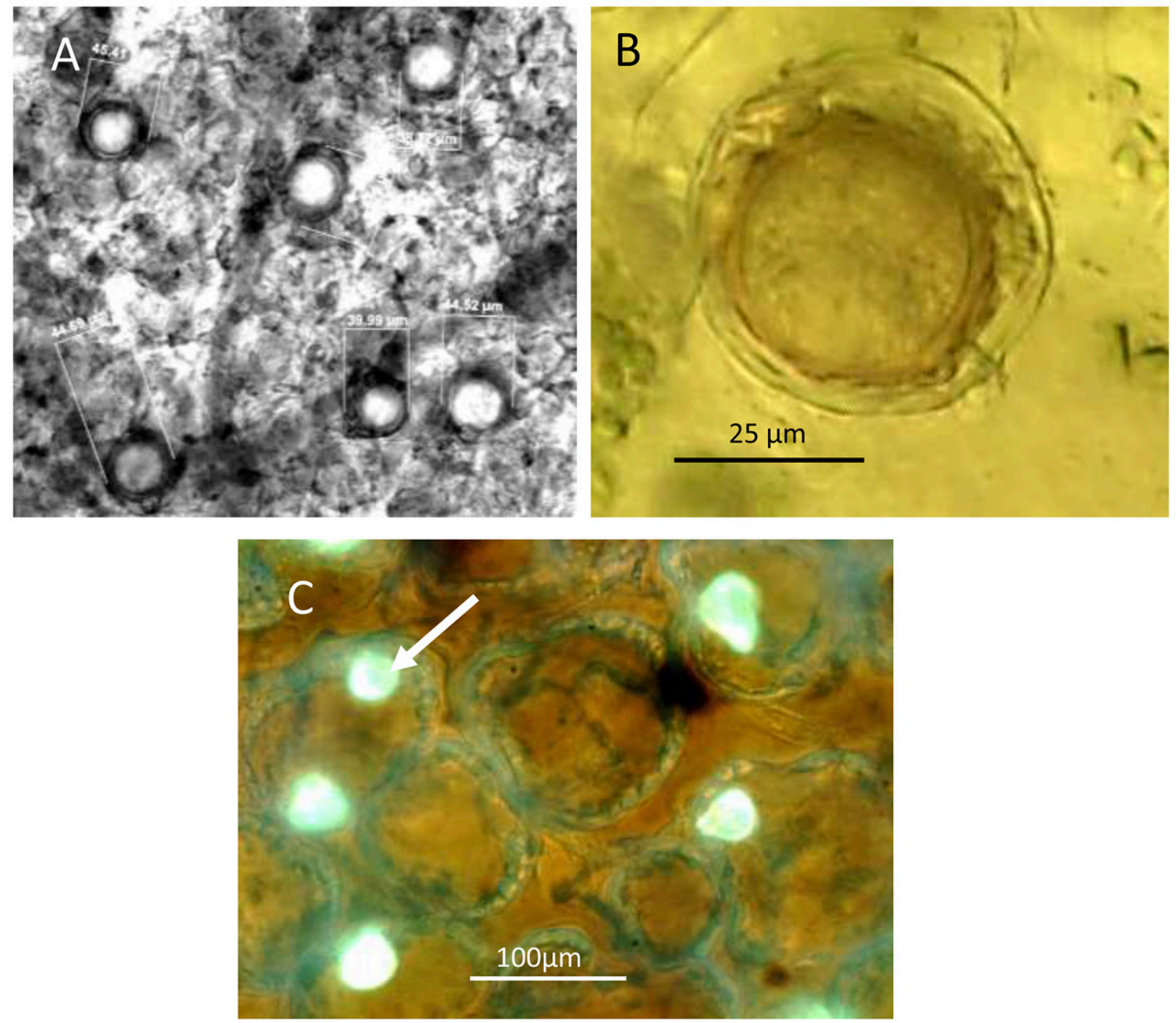


P. belbahrii inside mesophyll cells of a leaf of sweet basil. 
2 to $4 \mathrm{~h}$ are highly vulnerable to desiccation (Cohen and Ben Naim 2016).

\section{EFFECT OF LIGHT ON SPORULATION}

Light inhibits sporulation of $P$. belbahrii. Lopez-Lopez et al. (2014) reported that infected plants exposed to $24 \mathrm{~h}$ of light showed no sporulation, whereas similar plants exposed to $14 \mathrm{~h}$ light followed by $10 \mathrm{~h}$ darkness showed full sporulation. Treatments in which the $10 \mathrm{~h}$ darkness (D) period was interrupted with light (L) ( $3 \mathrm{~h} \mathrm{D} / 4 \mathrm{~h} \mathrm{~L}, 3 \mathrm{~h} \mathrm{D}$, or $2 \mathrm{~h} \mathrm{D} / 2 \mathrm{~h} \mathrm{~L} / 2 \mathrm{~h} \mathrm{D} / 2 \mathrm{~h} \mathrm{~L} / 2 \mathrm{~h} \mathrm{D}$ ) showed reduced or no sporulation.

Exposure to light suppresses spore formation but allows sporophores to emerge from stomata (Fig. 4A to D). Incandescent or cool
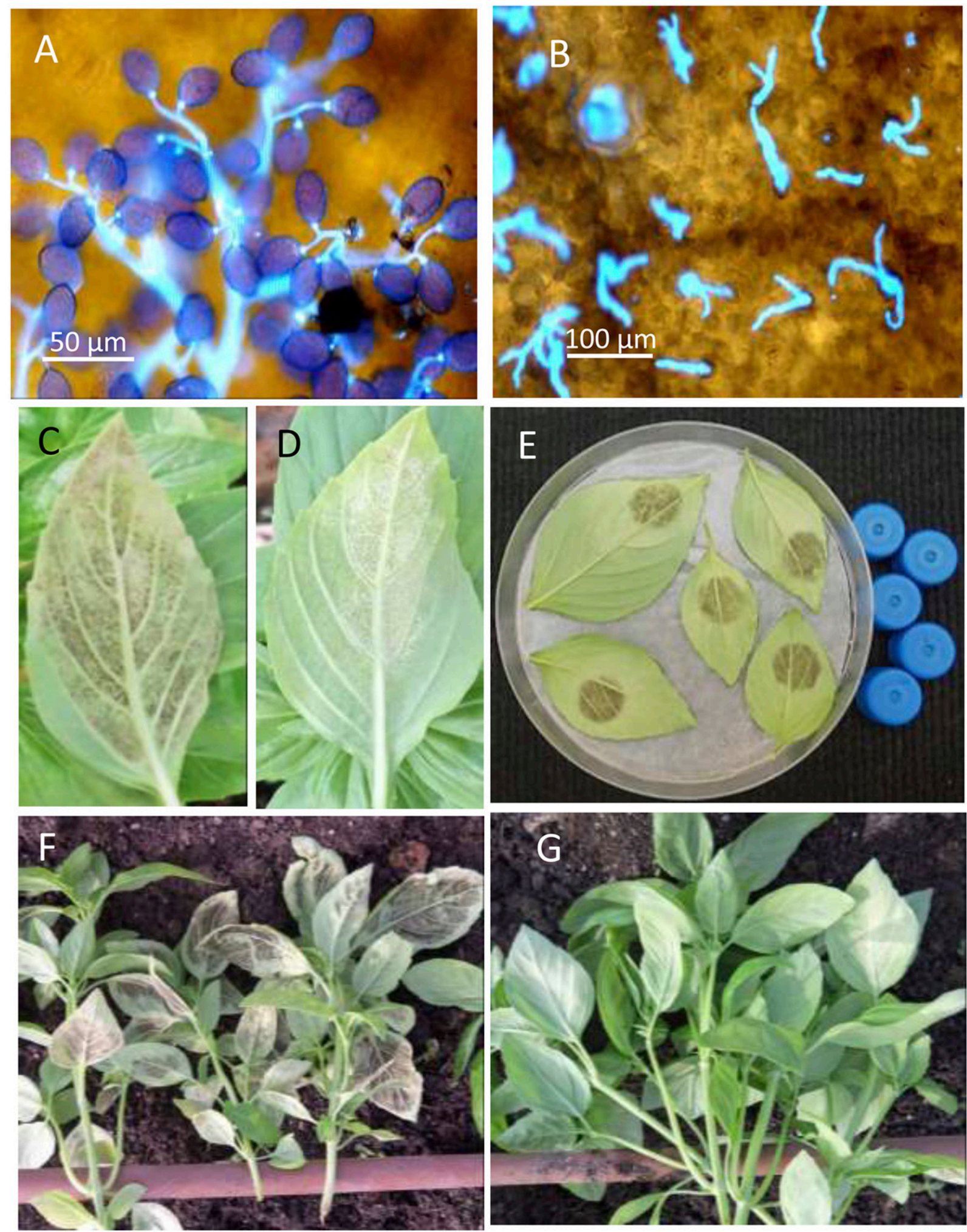

Fig. 4. The inhibitory effect of light on sporulation of Peronospora belbahrii on basil leaves. A and C, Sporulation on intact, infected leaves of basil developed in the dark at $20^{\circ} \mathbf{C}$. B and D, Sporophores produced in leaves incubated under CW fluorescent light. $\mathbf{E}$, No sporulation occurs on the surface of detached infected leaves exposed to light in moistened Petri dishes at $20^{\circ} \mathrm{C}$; sporulation occurs on only the shaded leaf tissue beneath plastic caps (removed). F, Abundant sporulation occurred on plants grown in a regular net-house. G, No sporulation occurred on plants grown in a net-house illuminated each night from 8:00 p.m. to 8:00 a.m. 
white fluorescent light of 3.5 or $6 \mu$ moles $\mathrm{m}^{-2} \mathrm{~s}^{-1}$, respectively, caused $100 \%$ inhibition of spore formation on lower leaf surface, even when the upper leaf surface was exposed to light. The inhibitory effect of light did not translocate from an illuminated part of a leaf to a shaded part of the same leaf (Fig. 4E). Inhibition of sporulation by light was temperature-dependent. Light was fully inhibitory at 15 to $25^{\circ} \mathrm{C}$ but not at $10^{\circ} \mathrm{C}$. Narrow band led illumination showed that red light $(\lambda \max 625 \mathrm{~nm})$ was most inhibitory while blue light $(\lambda \max 440 \mathrm{~nm})$ was least inhibitory, suggesting that inhibition in $P$. belbahrii operates via a red-light photoreceptor (Cohen et al. 2013a). Patel et al. (2016) confirmed the inhibitory effect of red light on sporulation of $P$. belbahrii in the spectrum of $625 \mathrm{~nm}$ wavelength illuminated at an average light intensity of $12 \mu \mathrm{mol} \mathrm{m} \mathrm{m}^{-2} \mathrm{~s}^{-1}$.

\section{SPORE DISPERSAL}

Potted, healthy basil plants served as spore traps to monitor spore dispersal of $P$. belbahrii from infected plants (unpublished data). The trap plants were introduced into net-houses (in which infected basil plants were growing) at 7:00 a.m., 9:00 a.m., 11:00 a.m., 1:00 p.m., or 3:00 p.m., and removed $2 \mathrm{~h}$ later (except $1 \mathrm{~h}$ for 3:00 p.m.) back to the laboratory. At 4:00 p.m. all plants were incubated in a dew chamber at $18^{\circ} \mathrm{C}$ in the dark for $15 \mathrm{~h}$ to allow for infection and then 6 days at $25^{\circ} \mathrm{C}$ for colonization and 1 day at $18^{\circ} \mathrm{C}$ in the dark to allow sporulation. Percent leaf area showing sporulation was an estimate of spore dispersal. The data presented in Figure 5 show the pattern of dispersal for 3 days in May 2015 along with the temperature and RH that prevailed in the net-houses. Dispersal occurred from 7:00 a.m. until 3: 00 p.m. It was strongly suppressed by the high temperature and low RH (15 to 20\%) that prevailed on a "hamsin" day of 18 May 2015 (Fig. 5C) probably because of poor spore survival (see below).

\section{SPORE SURVIVAL}

We tested the survival of attached spores of $P$. belbahrii as well as of detached spores (Cohen and Rubin 2015). In both, spore survival was determined by the ability of the spores to infect,


B
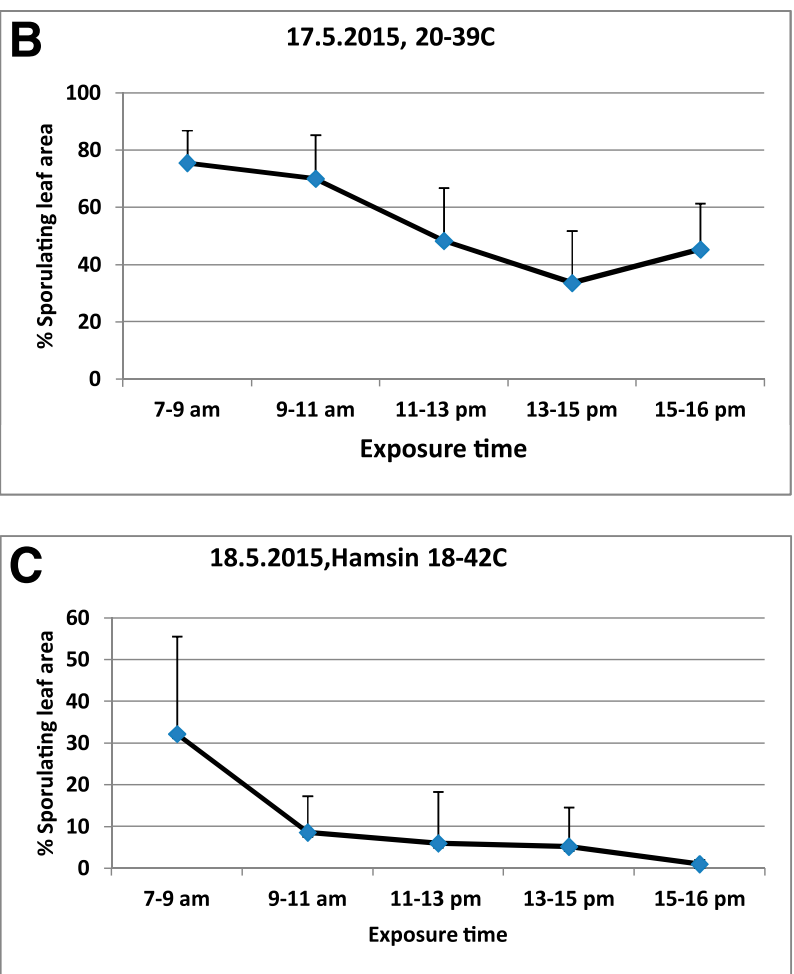
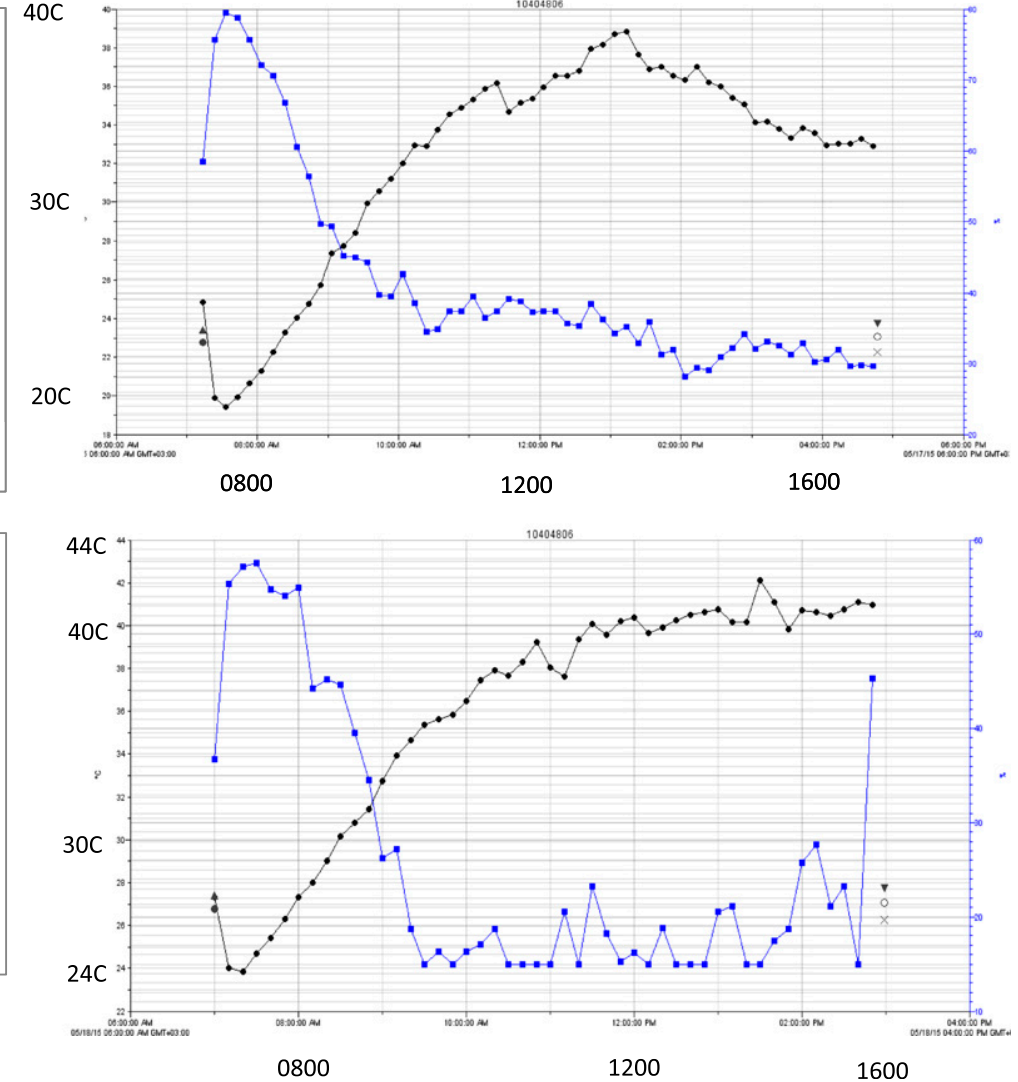

Fig. 5. Infectivity of dispersed spores of Peronospora belbahrii in three experiments conducted during 3 days in May 2015. Infectivity of the dispersed spores is shown in the left panels. Air temperature $\left({ }^{\circ} \mathrm{C}\right)$ and relative humidity $(\mathrm{RH} \%)$ are shown in the right panels. Temperature and $\mathrm{RH}$ ranged between $\mathbf{A}, 21$ to $34^{\circ} \mathrm{C}$ and 77 to $37 \%$; B, 19 to $39^{\circ} \mathrm{C}$ and 45 to $28 \%$; and $\mathbf{C}, 24$ to $42^{\circ} \mathrm{C}$ and 15 to $20 \%$. Hot and dry spells ("hamsin') occurred on 18 May 2015 (panel C). 
and subsequently sporulate on intact basil plants under optimal conditions. Infected potted plants, carrying abundant fresh spores, were exposed to a series of temperatures $\left(20\right.$ to $\left.45^{\circ} \mathrm{C}\right)$ for 3 to $96 \mathrm{~h}$.

Thereafter, the spores were collected and inoculated onto healthy basil plants to test their survival. Spore survival was strongly affected by temperature and duration of exposure. A longer exposure period and higher temperature weakened the infectious capacity of the spores. Spores collected after $3 \mathrm{~h}$ survived well at all temperatures, although viability declined at 40 and $45^{\circ} \mathrm{C}$. A sharp decline in spore survival occurred at $22 \mathrm{~h}$ and more so at 48 to $96 \mathrm{~h}$. No survival was seen after exposure to $45^{\circ} \mathrm{C}$ for $48 \mathrm{~h}, 35$ to $45^{\circ} \mathrm{C}$ for $72 \mathrm{~h}$, and 25 to $45^{\circ} \mathrm{C}$ for $96 \mathrm{~h}$.

Naturally dispersed spores lying on healthy basil plants retained some infectivity after exposure to 35 or $40^{\circ} \mathrm{C}$ for $31 \mathrm{~h}$, but lost it after exposure to 30,35 , or $40^{\circ} \mathrm{C}$ for $72 \mathrm{~h}$. Infectivity after exposure to $25^{\circ} \mathrm{C}$ for $48 \mathrm{~h}$ was low (about $20 \%$ ) and infectivity after exposure to $30^{\circ} \mathrm{C}$ for $48 \mathrm{~h}$ was lost (Cohen and Rubin 2015). Wetted-dried spores of $P$. belbahrii survived on the surface of basil leaves for up to $55 \mathrm{~h}$, depending on temperature. They lost infectivity after $9 \mathrm{~h}$ at $40^{\circ} \mathrm{C}, 20 \mathrm{~h}$ at $30^{\circ} \mathrm{C}$, or $55 \mathrm{~h}$ at $25^{\circ} \mathrm{C}$. Survivability of such spores was better in planta than in vitro (Cohen and Rubin 2015).

\section{MYCELIUM VIABILITY}

Sporulation capacity of $P$. belbahrii provided an estimate for mycelium viability in infected leaves. Exposure of infected basil plants at $7 \mathrm{dpi}$ to heat $\left(30,35\right.$, or $\left.45^{\circ} \mathrm{C}\right)$ was detrimental to sporulation of $P$. belbahrii. While a single 3 h exposure to heat had a minor effect on survival of the mycelium, three 3-h consecutive daily exposures, or one longer exposure, were strongly suppressive, especially at high temperatures. Thus, mycelium inside leaves did not survive exposure of 6 to $9 \mathrm{~h}$ to $40^{\circ} \mathrm{C}, 17 \mathrm{~h}$ to $35^{\circ} \mathrm{C}$, or $27 \mathrm{~h}$ to $30^{\circ} \mathrm{C}$. Exposure to heat was less suppressive when applied to infected plants at 5 dpi compared with plants at 7 or 9 dpi. This may be attributed to reduced sensitivity to heat of young mycelium (Cohen and Rubin 2015).

\section{SEXUAL LIFE CYCLE}

Little is known on oospore formation and their role in the epidemiology of BDM. Cohen et al. (2013c) reported on the infrequent occurrence of oospores of $P$. belbahrii inside the mesophyll of BDMinfected basil leaves. Oospores never occurred on the leaf surface but inside the mesophyll. Oospores are brown, round, $46.2 \pm 2.8 \mu \mathrm{m}$ in diameter (Fig. 3A and B). Inoculation of intact basil plants with spores of paired isolates from various years, various locations, or various hosts resulted in erratic oospore formation. No information is available on whether the pathogen is homothallic or heterothallic. Large-scale experiments were conducted to elucidate the pathogenicity of oospores to basil plants. Soil was infested with oospores (10 oospores $/ 5 \mathrm{~g}$ of soil/well) and three to four basil seeds were planted in each well. Plants were grown until the four-leaf stage, but none of the $\sim 2,000$ plants that developed showed symptoms of BDM nor sporulation of $P$. belbahrii.

\section{SEED TRANSMISSION}

The sudden appearance of BDM in Europe and its rapid spread to the Middle East, the United States, and Asia suggested that seeds or cuttings of basil might serve as a vehicle for dissemination of the causal pathogen $P$. belbahrii. Garibaldi et al. (2004b) tested, in two locations in Italy, basil seed samples from various sources. They observed downy mildew in 4 out of 16 samples at an incidence of 0.33 to $0.66 \%$. Belbahri et al. (2005) could detect DNA of P. belbahrii by PCR but failed to detect the pathogen on or in the seeds. Djalali Farahani-Kofoet et al. (2012) were able to detect $P$. belbahrii in artificially infested seeds at a DNA amount of a single spore per seed. $P$. belbahrii was detected in 80 to $90 \%$ of randomly investigated commercial seed stock samples, independent from the harvest year. Seeds collected from infected plants in the greenhouse produced $23 \%$ infected plants. Some were symptomless but carried the DNA of $P$. belbahrii in their stems or leaves. Systemic growth of $P$. belbahrii within plants was observed in leaves and stem sections of symptomless plants (Djalali FarahaniKofoet et al. 2012). Gilardi et al. (2015) showed reduced disease incidence when infected seeds were treated with hot air $\left(65^{\circ} \mathrm{C}\right.$ for $10 \mathrm{~min}$ ) before seeding.

In contrast to these findings, we could not demonstrate the transmission of $P$. belbahrii via seeds of sweet basil. Seeds collected from heavily infected plants during three seasons produced upon planting in growth chambers $\left(22^{\circ} \mathrm{C}, 60\right.$ to $\left.70 \% \mathrm{RH}\right)$ healthy plants only. Upon onset of RH 100\% in dew chambers, none of these plants exhibited sporulation of the pathogen. Microscopic examination of such seeds, before sowing, revealed neither mycelium nor spores of the pathogen in the embryo. Furthermore, tetrads of seeds, with their BDM-infected calyx leaves attached, produced healthy plants and none exhibited sporulation of the pathogen when planted in sterile soil in growth chambers. The origin of the disease in Israel in 2011 remains therefore obscure. Import of infected cuttings, longdistance travel of the spores by wind or birds may be plausible.

\section{SYSTEMIC INFECTION}

The finding that DNA of $P$. belbahrii occurs in basil stems (Djalali Farahani-Kofoet et al. 2012) indicated that mycelium of the pathogen can translocate from an infected leaf to a distal leaf via the stem. To test this hypothesis, we conducted the following experiment: the second pair of leaves of eight-leaf healthy basil plants were drop-inoculated with spore suspension of $P$. belbahrii and kept at $100 \% \mathrm{RH}$ in the dark for $15 \mathrm{~h}$ to allow infection. The plants were than maintained at $25^{\circ} \mathrm{C}, 60 \% \mathrm{RH}$ for 10 days, and then placed in a dew chamber for $15 \mathrm{~h}$ to allow sporulation. In one experiment, 12 out 60 plants, and in another experiment 6 out of 20 plants showed sporulation in top, noninoculated leaves, suggesting systemic movement of the pathogen from the bottom inoculated leaves to upper, noninoculated leaves via the stem. Indeed, longitudinal sections taken from such plants revealed mycelium of the pathogen inside the stem. Control noninoculated plants showed no sporulation. Systemic infection in nature is very rare. In only one case have we detected a single plant with systemic infection in the greenhouse. It seems that the proneness of basil plants to systemic infection declines with age.

\section{DISEASE CONTROL BY NOCTURNAL ILLUMINATION}

As mentioned above, exposure of infected basil plants to light (during the sporulation phase) suppresses spore formation of $P$. belbahrii (Cohen et al. 2013a; López-López et al. 2014). Nocturnal illumination of basil crops in the field ( 4 to $10 \mu$ moles $\mathrm{m}^{-2} \mathrm{~s}^{-1}$ ) from 7:00 p.m. to 7:00 a.m. suppressed sporulation of P. belbahrii (Fig. 3E and F) and thus diminished the epidemics of downy mildew (Cohen et al. 2013a).

\section{DISEASE CONTROL BY DAYTIME SOLAR HEATING}

Growth chamber studies showed that $P$. belbahrii was sensitive to exposure to high temperature. Exposure of spores, infected leaves, or infected plants to 35,40 , or $45^{\circ} \mathrm{C}$ for 6 to $9 \mathrm{~h}$ suppressed its survival (Cohen and Rubin 2015). Therefore, daytime solar heating was employed to basil crops in net-houses to control BDM. Covering net-houses of sweet basil, already infected with downy mildew, with transparent, infrared-impermeable, polyethylene sheets raised the daily maximal temperature during sunny hours by 11 to $22^{\circ} \mathrm{C}$ reaching 40 to $58^{\circ} \mathrm{C}$ (greenhouse effect). Such coverage, applied for a few hours during 1 to 3 consecutive days, had a detrimental effect on survival of $P$. belbahrii, killing the 
pathogen and suppressing disease progress while enhancing growth of the host basil plants (Cohen and Rubin 2015).

Elad et al. (2016) performed regression analyses between BDM values in plastic tunnels and air temperature, $\mathrm{RH}$, and soil temperature. Downy mildew severity was negatively related to high $\left(>25^{\circ} \mathrm{C}\right)$ air temperature, $\mathrm{RH}$ in the range of 65 to $85 \%$, and high $\left(>21^{\circ} \mathrm{C}\right)$ soil temperature. At high temperatures, symptom expression/tissue colonization was suppressed. Pot experiments revealed that exposing the roots to high temperature $\left(26\right.$ to $31^{\circ} \mathrm{C}$ ), while maintaining the upper plant parts at ambient temperature $\left(20^{\circ} \mathrm{C}\right)$, suppresses downy mildew. They concluded that the suppressive effect of high greenhouse temperature on basil downy mildew may not result from a direct negative effect on the pathogen but from an indirect high-temperature effect on the host, rendering it less susceptible to pathogen development.

\section{DISEASE CONTROL BY FANNING}

Spores of $P$. belbahrii require $\geq 4 \mathrm{~h}$ free leaf moisture for infection and $\geq 7.5 \mathrm{~h}$ of water-saturated atmosphere $(\mathrm{RH} \geq 95 \%)$ at night for sporulation. We showed (Cohen and Ben-Naim 2016) that BDM epidemics may be controlled in basil crops by manipulating $\mathrm{RH}$ and leaf wetness duration by fanning. Nocturnal fanning (wind speed of 0.4 to $1.5 \mathrm{~m} / \mathrm{s}$ ) from 8:00 p.m. to 8:00 a.m., applied to basil crops growing in net-houses or plastic houses, dramatically suppressed downy mildew development. In three experiments conducted during 2015, percent infected leaves in regular (nonfanned) nethouses reached a mean of $89.9,94.3$, and $96.0 \%$ compared with 1.2 , 1.7 , and $0.5 \%$ in adjacent fanned net-houses, respectively (Fig. 6A to F). Nocturnal fanning reduced the number of hours per night with $\mathrm{RH} \geq 95 \%$ thus shortened the dew periods below the threshold required for infection or sporulation. In these experiments, the number of nights with $\geq 4$ h of $\mathrm{RH} \geq 95 \%$ was 28,10 , and 17 in the nonfanned net-houses compared with five, zero, and five in the fanned net-houses, respectively. Leaf wetness sensors showed that dew formation was strongly suppressed in the fanned net-house compared with the nonfanned net-house. Healthy potted plants became infected and sporulated a week later if placed one night in the nonfanned house, whereas healthy plants placed during that night in the fanned house
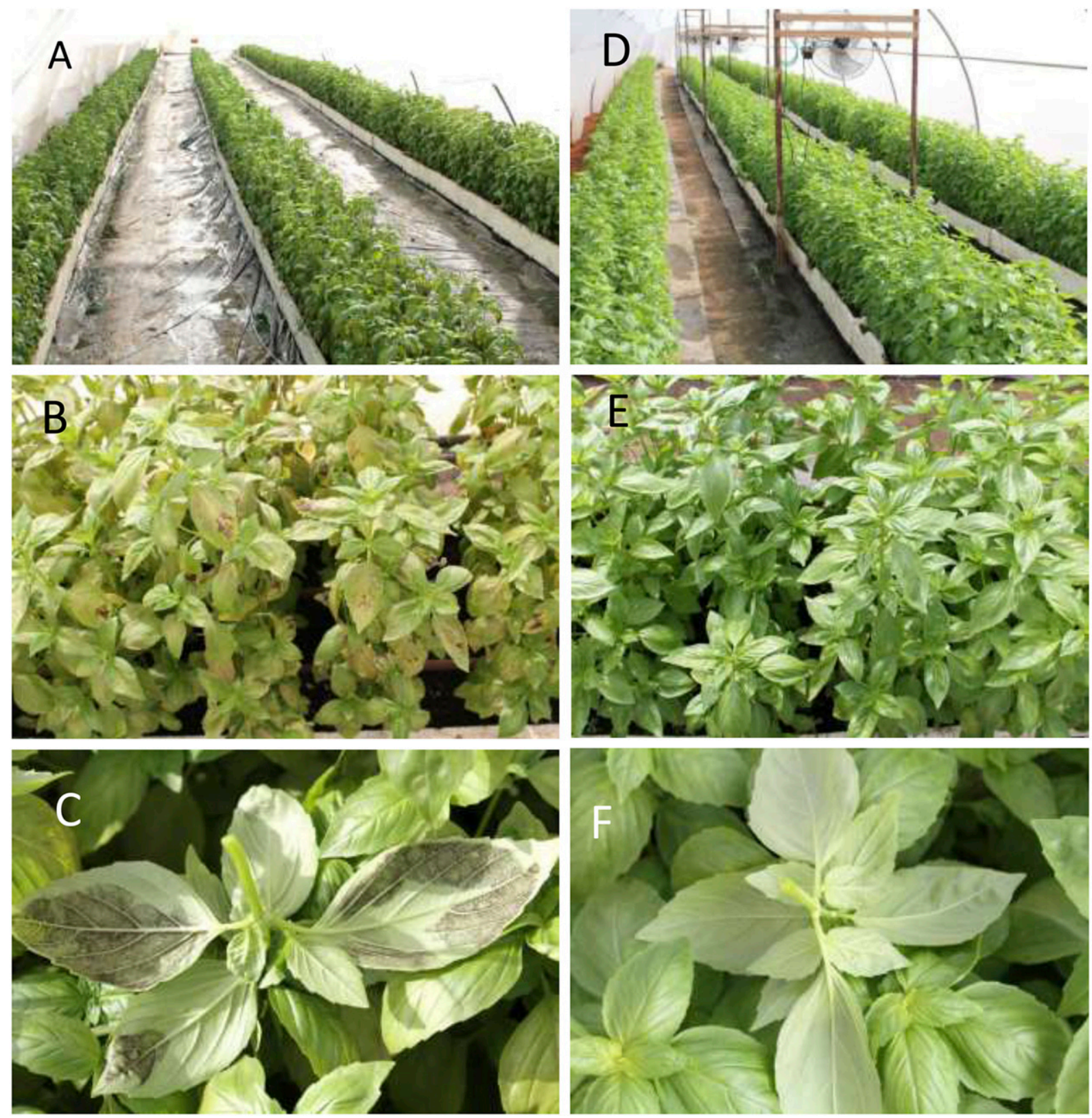

Fig. 6. The appearance of basil crops grown under A to C, regular versus D to F, nocturnal fanning conditions in two net-houses during summer 2015 . B and C show disease in A. E and F show no disease in D. Note the fans above the crop in D. 
remained healthy. Infected potted basil plants sporulated heavily after one night of incubation in the nonfanned house, whereas almost no sporulation occurred in similar plants incubated that night in the fanned house (Cohen and Ben-Naim 2016). These data suggest that nocturnal fanning is highly effective in suppressing BDM epidemics in sweet basil. Fanning prevented the within-canopy RH from reaching saturation, reduced dew deposition on the leaves, and hence prevented both infection and sporulation of $P$. belbahrii.

To save electricity, fanning in 2016 experiments, was controlled by a computer-controlled RH-sensor. The program allowed operating the fans at any desired RH during the day. When fans were operated at RH $80 \%$ and stopped at $70 \%$ control of the disease was poor, but when operated at RH $70 \%$ and stopped at $65 \%$, control of the disease was excellent (unpublished data). Our recommendation to farmers is to start fanning when RH reaches $70 \%$ and stop it when RH drops to $65 \%$.

\section{GENETIC RESISTANCE}

Homa et al. (2016) examined the susceptibility to downy mildew of 20 Ocimum species. Sweet basils were determined to be the most susceptible; cinnamon, clove, and Thai types (all Ocimum basilicum) were moderately susceptible; and citrus $($ O. $\times$ citrodorum $)$, spice (O. americanum), and holy types (O. tenuiflorum) were least susceptible to downy mildew. Using the same 20 Ocimum species and cultivars, stomata length, density, and leaf curvature were correlated with downy mildew incidence and severity. Basil species with higher stomatal densities had higher downy mildew incidence and severity. High stomatal densities were mainly found in the sweet, cinnamon, and clove basils. Citrus and spice species with longer stomatal lengths exhibited lower downy mildew incidence. A departure from these trends is holy basil, the least susceptible of all Ocimum sp. to $P$. belbahrii, which had the greatest stomatal density and shortest stomatal length. Some sweet basil cultivars with the highest downy mildew incidence also had the greatest downward leaf curvature, whereas other sweet basil cultivars with moderate downy mildew incidence had leaves that were nearly flat or curved upward. Holy, citrus, and spice basils with low downy mildew incidence had leaves that were nearly flat or curved upward (Homa et al. 2016).

Several studies were conducted to identify sources of resistance against BDM in $O$. basilicum cultivars, O. basilicum variants, Ocimum spp., and wild Ocimum Plant Introductions (available at USDA-National Plant Germplasm System). No resistance was found in $O$. basilicum but tolerance was found in nonsweet basil phenotypes (Ben-Naim et al. 2015; Djalali Farahani-Kofoet et al.
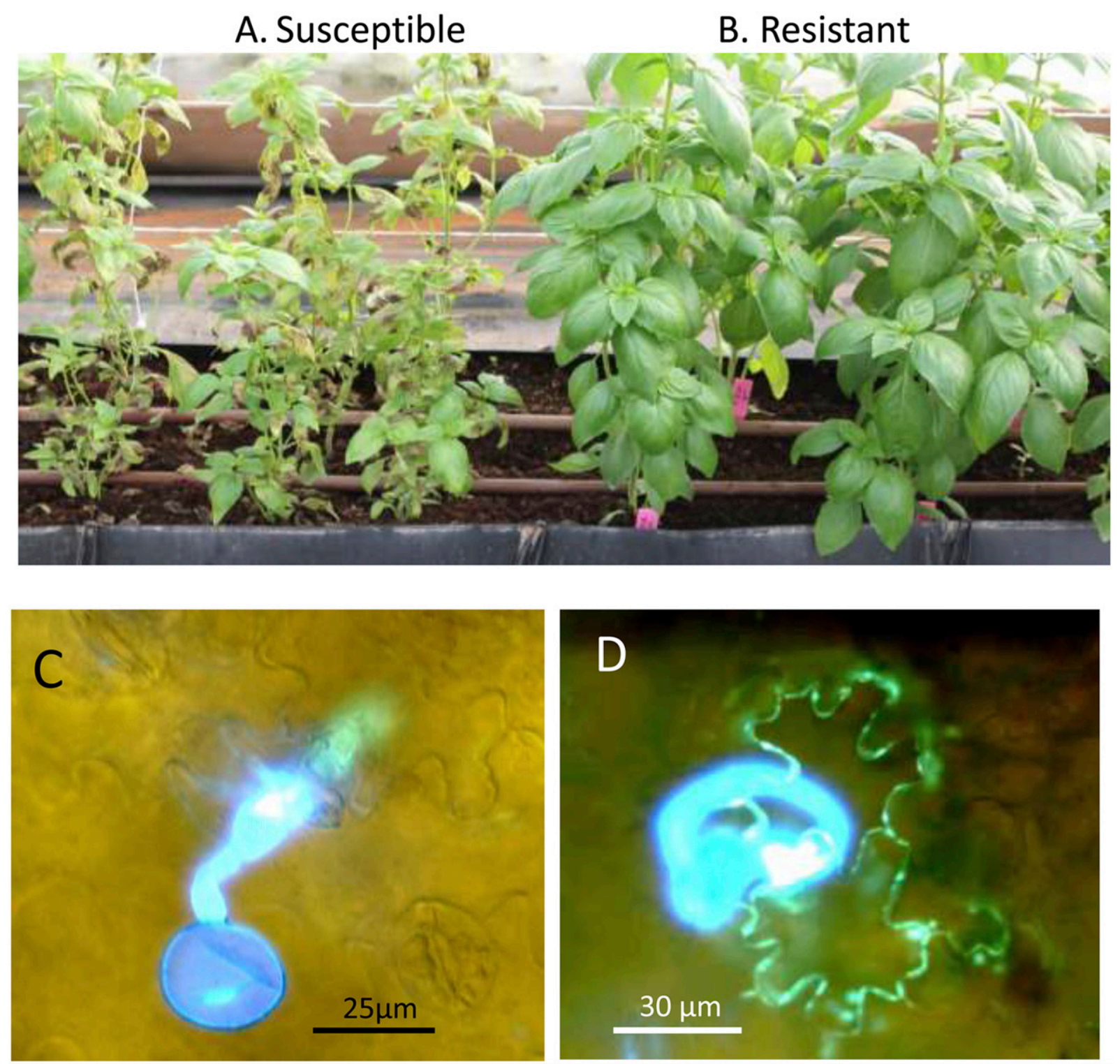

Fig. 7. Genetic resistance against Peronospora belbahrii in sweet basil. The appearance of downy mildew on A, susceptible line and B, resistant line of sweet basil growing side by side in a net-house. C, Penetration of the pathogen into the epidermis of the susceptible line. D, Penetration of the pathogen into the epidermis of the resistant line. Note in $\mathrm{C}$ the initial growing hypha in the mesophyll. Note in $\mathrm{D}$ the encasement with callose of the penetrated cell. 
2012; Koroch et al. 2013; Pyne et al. 2014; Romer et al. 2010; Wyenandt et al. 2010). The lemon chemo type basil varieties within O. basilicum var. citriodorum variant (PI 652054 'Mrs. Burns', PI 253157, and PI 296391), O. xcitriodorum 'Sweet Danni', and $O$. americanum 'Lime' demonstrated reduced disease levels with low sporulation in response to inoculation with the downy mildew agent (Ben-Naim et al. 2015; Djalali Farahani-Kofoet et al. 2012; Wyenandt et al. 2010). Other $O$. basilicum variants such as O. basilicum var. minimum (PI 170579 and PI 170581) and the Thai basil $O$. basilicum var. thyrsiflorum (PI 211586) demonstrated reduced disease levels and low sporulation. The PI accessions PI 172996, PI 172997, PI 172998, and PI 174284, belonging to O. basilicum var. anisatum were highly tolerant, exhibiting a few restricted chlorotic lesions with sparse sporulation (Ben-Naim et al. 2015; Pyne et al. 2014). Complete resistance was reported in the noncommercial cultivars 'Spice' (Ocimum spp.), 'Blue Spice' (O. americanum $\times$ O. basilicum), and 'Lime basil' (O. americanum) (Wyenandt et al. 2010). However, these genotypes showed incomplete resistance against Israeli isolates (Ben Naim et al. 2015). Further screening of wild Ocimum genotypes for downy mildew resistance revealed high level of resistance in $O$. americanum var. americanum, O. americanum var. pilosum, O. campechianum, $O$. micranthum 'Peruvian basil', $O$. gratissimum, and $O$. tenuiflorum Syn-O. sanctum, 'Tulsi' (Ben-Naim et al. 2015; Djalali FarahaniKofoet et al. 2014). Evaluations made during 3 years at BIU Farm (Israel) under heavy inoculum pressures revealed three immune O. americanum accessions, PI 500945, PI 500950, PI 652053, and one O. kilimandsharicum accession PI 652052 (Ben-Naim et al. 2015). Out of 27 hybrids made between resistant accessions and the susceptible 'Peri', 21 showed partial resistance to the disease and three hybrids [(made with the resistant entries PI 500950 (O. americanum var. pilosum), PI 500945 (O. americanum var. americanum), and PI 500951 (O. americanum var. pilosum)] showed full resistance, suggesting a dominant gene(s) for resistance. Unfortunately, all these resistant genotypes represented exotic basils, differing greatly in morphology, aromas and taste from sweet basil. Furthermore, all three immune parental lines exhibited sexual incompatibility with sweet basil producing sterile $\mathrm{F} 1$ hybrids due to ploidy differences and lack of chromosomes homology (Ben-Naim et al. 2015; Carovic-Stanko et al. 2010; Paton and Putievsky 1996). Restoration of fertility and substantial back cross breeding are required for successful introgression of these resistance genes into sweet basil.

Ben Naim et al. (2016) used embryo rescue procedures to overcome interspecies infertility barriers among Ocimum species. BDM resistant, interspecies F1 hybrid plants were pollinated with pollen of sweet basil. Fertilized F1 ovules were rescued, cultured in vitro, rooted and grown in the green house. BDM resistant BC1 plants showing some female fertility were backcrossed again to sweet basil. After the third back cross plants were resistant and fully fertile (Fig. 7A and B). Progeny analysis suggested that a single dominant gene controls resistance. Further selection resulted in resistant progeny plants with elite horticultural and aroma properties.

MR1 was used as a resistance source by Pyne et al. (2015) at Rutgers University (New Jersey). These authors crossed MRI (resistant parent, $\mathrm{P} 1) \times \mathrm{SB} 22$ (susceptible parent, $\mathrm{P} 2$ ) and evaluated the resistance of F1, $\mathrm{F} 2, \mathrm{BC} 1 \mathrm{P} 1$, and $\mathrm{BC} 1 \mathrm{P} 2$ to downy mildew. They concluded that two genes with digenic epistasis control resistance in this family.

\section{CHEMICAL CONTROL}

Several reports were published on chemical control of BDM (Babadoost 2010; Cohen et al. 2015; Gilardi et al. 2013; Homa et al. 2014; McGrath 2016; Mersha et al. 2012, 2013; Patel et al. 2014a, b; Raid et al. 2010; Wyenandt et al. 2015). In the United States, two labeled fungicides, mono- and di-potassium salts of phosphorous acid, Pro-Phyt and K-Phite, provided the most efficacious control of basil downy mildew compared with other conventional and organic fungicides (Homa et al. 2014).
Mefenoxam (MFX, Ridomil-Gold) was highly effective against BDM until the appearance of MFX-resistant isolates in Israel (Cohen et al. 2013c) and Italy (Collina et al. 2016), which have rendered it ineffective. Interestingly, phosphorous acid-based fungicides, which were effective in field trials in Israel during 2012-13, lose efficacy in 2014-16 when MFX-resistant isolates dominated the fungal population (unpublished data).

We found several fungicides (alone or in combination) effective against BDM in growth chamber and field trials. The following fungicides (FRAC code number follows) were highly effective (ED $90 \leq 10$ ppm a.i.) in potted plants: azoxistrobin (11), cyazofamid (21), dimethomorph (40), mandipropamid (40), famoxadone (45), fenamidone (45), fluopicolide (43), and initium (no FRAC code). The following fungicides were moderately effective (ED $90>10$ but below 100 ppm a.i.): mancozeb (M3), chlorothalonil (M5), and copper-based fungicides (M1) (Cohen et al. 2015) (unpublished data). Two fungicide applications given to basil seedlings in the nursery house (dimethomorph or mandipropamid at cotyledon stage and azoxystrobin at the two-leaf stage) provided full protection to the transplants against BDM in the field for 3 to 4 weeks.

The new anti-oomycete fungicide oxathiapiproline (FRAC code 49) was highly effective against MFX-sensitive and MFX-resistant isolates of $P$. belbahrii, also exhibiting good curative efficacy (Cohen 2015, 2016; Patel et al. 2014a). In the field, complete control of BDM was achieved all season with three foliar sprays of 12.5-ppm a.i. of this fungicide (unpublished data).

Mersha et al. (2012, 2013) and Cohen et al. (2015) reported on the control of BDM with the chemical inducer BABA ( $\beta$-aminobutyric acid).

\section{ACKNOWLEDGMENTS}

This research was supported by Research Grant US-4947-16 R from BARD, the United States-Israel Binational Agricultural Research and Development Fund and by research grants from The Plant Council, Israel.

\section{LITERATURE CITED}

Babadoost, M. 2010. Downy mildew of basil in Illinois. (Abstr.) Phytopathology 100(suppl.):S9.

Bastidas, M. R., Picazo, L. S., Amador, B. M., Garibay, A. N., Barragan, H. L., and Montiel, L. G. H. 2016. First report of Peronospora belbahrii on sweet basil in Baja California Sur, Mexico. J. Phytopathol. 164:122-124.

Belbahri, L., Calmin, G., Lefort, F., and Pawlowski, J. 2005. Phylogenetic analysis and real time PCR detection of a new Peronospora species responsible for downy mildew disease of sweet basil and sage. Mycol. Res. 109:1276-1287.

Ben-Naim, Y., Falach, L., and Cohen, Y. 2015. Resistance against basil downy mildew in Ocimum species. Phytopathology 105:778-785.

Ben Naim, Y., Falach, L., and Cohen, Y. 2016. Transfer of resistance against downy mildew from wild basil to sweet basil. Phytoparasitica 44:275.

Blomquist, C. L., Rooney-Latham, S., and Nolan, P. A. 2009. First report of downy mildew on field-grown sweet basil caused by a Peronospora sp. in San Diego County, California. Plant Dis. 93:968.

Carovic-Stanko, K., Liber, Z., Besendorfer, V., Javornik, B., Bohanec, B., Kolak, I., and Satovic, Z. 2010. Genetic relations among basil taxa (Ocimum L.) based on molecular markers, nuclear DNA content, and chromosome number. Plant Sys. Evol. 285:13-22.

Chen, C. H., Huang, J. H., and Hsieh, T. F. 2010. First report of Peronospora belbahrii causing downy mildew on basil. Plant Pathol. Bull. 19:177-180.

Choi, Y. J., Choi, I. Y., Lee, K. J., and Shin, H. D. 2016. First report of downy mildew caused by Peronospora belbahrii on sweet basil (Ocimum basilicum) in Korea. Plant Dis. 100:2335.

Choi, Y. J., Shin, H. D., and Thines, M. 2009. Two novel Peronospora species are associated with recent reports of downy mildew on sages. Mycol. Res. 113:1340-1350.

Cohen, Y. 2015. The novel oomycide oxathiapiprolin inhibits all stages in the asexual life cycle of Pseudoperonospora cubensis-Causal agent of cucurbit downy mildew. PLoS One 10:e0140015.

Cohen, Y. 2016. ORONDISTM Opti, a new anti-oomycete fungicide active against late blight and downy mildews. Phytoparasitica 44:278.

Cohen, Y., and Ben-Naim, Y. 2016. Nocturnal fanning suppresses downy mildew epidemics in sweet basil. PLoS One 11:e0155330. 
Cohen, Y., and Rubin, A. E. 2015. Daytime solar heating controls downy mildew Peronospora belbahrii in sweet basil. PLoS One 10:e0126103.

Cohen, Y., Rubin, A. E., Liu, X. L., Wang, W. Q., Zhang, Y. J., and Hermann, D. 2013b. First report on the occurrence of A2 mating type of the cucurbit downy mildew agent Pseudoperonospora cubensis in China. Plant Dis. 97: 559.

Cohen, Y., Vaknin, M., and Ben Naim, Y. 2015. Chemical control of downy mildew in basil caused by Peronospora belbahrii. Phytoparasitica 43: 381.

Cohen, Y., Vaknin, M., Ben-Naim, Y., and Rubin, A. E. 2013a. Light suppresses sporulation and epidemics of Peronospora belbahrii. PLoS One 8: e81282.

Cohen, Y., Vaknin, M., Ben-Naim, Y., Rubin, A. E., Galperin, M., Silverman, D., Bitton, S., and Adler, U. 2013c. First report of the occurrence and resistance to mefenoxam of Peronospora belbahrii, causal agent of downy mildew of basil (Ocimum basilicum) in Israel. Plant Dis. 97:692.

Collina, M., Merighi, M., Turan, C., Pirondi, A., Minuto, G., and Brunelli, A. 2016. First report of resistance of Peronospora belbahrii, causal agent of downy mildew of basil, to mefenoxam in Italy. Plant Dis. 100:1787.

Coosemans, J. 2004. First report of Peronospora lamii, downy mildew on basil (Ocimum basilicum) in Belgium. Parasitica 60:27.

Denton, G. J., Beal, E., Denton, J. O., and Clover, G. 2015. First record of downy mildew, caused by Peronospora belbahrii, on Solenostemon scutellarioides in the UK. New Dis. Rep. 31:14.

Djalali Farahani-Kofoet, R., Romer, P., and Grosch, R. 2012. Systemic spread of downy mildew in basil plants and detection of the pathogen in seed and plant samples. Mycol. Prog. 11:961-966.

Djalali Farahani-Kofoet, R., Römer, P., and Grosch, R. 2014. Selecting basil genotypes with resistance against downy mildew. Sci. Hortic. (Amsterdam) 179:248-255.

Elad, Y., Omer, C., Nisan, Z., Harari, D., Goren, H., Adler, U., Silverman, D., and Biton, S. 2016. Passive heat treatment of sweet basil crops suppresses Peronospora belbahrii downy mildew. Ann. Appl. Biol. 168:373-389.

Farr, D. F., and Rossman, A. Y. 2015. Fungal Databases, Systematic Mycology and Microbiology Laboratory, ARS, USDA. https://nt.ars-grin.gov/ fungaldatabases

Garibaldi, A., Bertetti, D., and Gullino, M. L. 2007. Effect of leaf wetness duration and temperature on infection of downy mildew (Peronospora sp.) of basil. J. Plant Dis. Prot. 114:6-8.

Garibaldi, A., Minuto, A., and Gullino, M. L. 2005. First report of downy mildew caused by Peronospora sp. on basil (Ocimum basilicum) in France. Plant Dis. 89:683.

Garibaldi, A., Minuto, A., Minuto, G., and Gullino, M. L. 2004a. First report of downy mildew on basil (Ocimum basilicum) in Italy. Plant Dis. 88:312.

Garibaldi, A., Minuto, G., Bertetti, D., and Gullino, M. L. 2004b. Seed transmission of Peronospora sp. of basil. J. Plant Dis. Prot. 111:465469.

Gilardi, G., Demarchi, S., Garibaldi, A., and Gullino, M. L. 2013. Management of downy mildew of sweet basil (Ocimum basilicum) caused by Peronospora belbahrii by means of resistance inducers, fungicides, biocontrol agents and natural products. Phytoparasitica 41:59-72.

Gilardi, G., Pintore, I., Demarchi, S., Gullino, M. L., and Garibaldi, A. 2015. Seed dressing to control downy mildew of basil. Phytoparasitica 43: 531-539.

Hansford, C. G. 1933. Annual report of the mycologist. Rev. Appl. Mycol. 12: 421-422.

Harlan, B., Linderman, S., Hyatt, L., and Hausbeck, M. 2015. Research gives clues for preventing coleus downy mildew. Greenhouse Grower. Published online.

Henricot, B., Denton, J., Scrace, J., Barnes, A. V., and Lane, C. R. 2010. Peronospora belbahrii causing downy mildew disease on Agastache in the UK: A new host and location for the pathogen. Plant Pathol. 59: 801 .

Homa, K., Barney, W. P., Ward, D. L., Wyenandt, C. A., and Simon, J. E. 2014. Evaluation of fungicides for the control of Peronospora belbahrii on sweet basil in New Jersey. Plant Dis. 98:1561-1566.

Homa, K., Barney, W. P., Ward, D. L., Wyenandt, C. A., and Simon, J. E. 2016. Morphological characteristics and susceptibility of basil species and cultivars to Peronospora belbahrii. HortScience 51:1389-1396.

Kanetis, L., Vasiliou, A., Neophytou, G., Samouel, S., and Tsaltas, D. 2014. First report of downy mildew caused by Peronospora belbahrii on sweet basil (Ocimum basilicum) in Cyprus. Plant Dis. 98:283.

Khateri, H., Calmin, G., Moarrefzadeh, N., Belbahri, L., and Lefort, F. 2007. First report of downy mildew caused by Peronospora sp. on basil in northern Iran. J. Plant Pathol. 89:S70.

Kong, X. Y., Wang, S., Wan, S. L., Xiao, C. L., Luo, F., and Liu, Y. 2015. First report of downy mildew on basil (Ocimum basilicum) in China. Plant Dis. 99:1642-1643.
Koroch, A. R., Villani, T. S., Pyne, R. M., and Simon, J. E. 2013. Rapid staining method to detect and identify downy mildew (Peronospora belbahrii) in basil. Appl. Plant Sci. 1:1300032.

López-López, A., Koller, M., Herb, C., and Scharer, H. J. 2014. Influence of light management on the sporulation of downy mildew on sweet basil. II International Symposium on Organic Greenhouse Horticulture 1041:213219.

Martinez de la Parte, E., Perez-Vicente, L., Bernal, B., and Garcia, D. 2010. First report of Peronospora sp. on sweet basil (Ocimum basilicum) in Cuba. Plant Pathol. 59:800.

McGrath, M. T. 2016. Efficacy of fungicides, biopesticides, and resistant varieties for managing downy mildew in basil. (Abstr.) Phytopathology 106 (suppl.):S4.

McGrath, M. T., Wyenandt, A., and Simon, J. E. 2010a. Downy mildew wars: A monitoring program can help growers determine if the basil downy mildew pathogen is present in their area. Growing Produce 10:8.

McGrath, M. T., Wyenandt, C. A., Raid, R. N., Babadoost, M., and Wick, R. L. 2010b. Occurrence of basil downy mildew in the eastern US in 2009. (Abstr.) Phytopathology 100(suppl.):S196.

McLeod, A., Coertze, S., and Mostert, L. 2006. First report of a Peronospora species on sweet basil in South Africa. Plant Dis. 90:1115.

Mersha, Z., Zhang, S., Fu, Y., Mo, X., Raid, R. N., and Hau, B. 2013. Efficacy of acibenzolar-S-methyl and beta-aminobutyric acid for control of downy mildew in greenhouse grown basil and peroxidase activity in response to treatment with these compounds. J. Phytopathol. 161: 154-164

Mersha, Z., Zhang, S. A., and Raid, R. N. 2012. Evaluation of systemic acquired resistance inducers for control of downy mildew on basil. Crop Prot. 40:83-90.

Nagy, G., and Horvath, A. 2011. Occurrence of downy mildew caused by Peronospora belbahrii on sweet basil in Hungary. Plant Dis. 95: 1034.

Patel, J. S., Zhang, S., and de Novaes, M. I. C. 2014a. Oxathiapiprolin: An effective new chemistry for control of downy mildew of basil. (Abstr.) Phytopathology 104(suppl.):S90.

Patel, J. S., Zhang, S. A., and de Novaesi, M. I. C. 2014b. Effect of plant age and acibenzolar-S-methyl on development of downy mildew of basil. HortScience 49:1392-1396.

Patel, J. S., Zhang, S. A., and McGrath, M. T. 2016. Red light increases suppression of downy mildew in basil by chemical and organic products. J. Phytopathol. 164:1022-1029.

Paton, A., and Putievsky, E. 1996. Taxonomic problems and cytotaxonomic relationships between and within varieties of Ocimum basilicum and related species (Labiatae). Kew Bull. 51:509-524.

Petrzelova, I., Kitner, M., Dolezalova, I., Ondrej, V., and Lebeda, A. 2015. First report of basil downy mildew caused by Peronospora belbahrii in the Czech Republic. Plant Dis. 99:418.

Porta-Puglia, A., and Mifsud, D. 2006. First record of downy mildew caused by Peronospora sp. on basil in Malta. J. Plant Pathol. 88:124.

Pyne, R. M., Koroch, A. R., Wyenandt, C. A., and Simon, J. E. 2014. A rapid screening approach to identify resistance to basil downy mildew (Peronospora belbahrii). HortScience 49:1041-1045.

Pyne, R. M., Koroch, A. R., Wyenandt, C. A., and Simon, J. E. 2015. Inheritance of resistance to downy mildew in sweet basil. J. Am. Soc. Hortic. Sci. 140:396-403

Raid, R. N., Roberts, P. D., Harmon, P. F., Palmateer, A. J., and Jordan, S. A. 2010. Basil downy mildew in Florida: A disease of new importance. (Abstr.) Phytopathology 100(suppl.):S175.

Rivera, Y., Salgado-Salazar, C., Windham, A. S., and Crouch, J. A. 2016. Downy mildew on Coleus (Plectranthus scutellarioides) caused by Peronospora belbahrii sensu lato in Tennessee. Plant Dis. 100:655.

Roberts, P. D., Raid, R. N., Harmon, P. F., Jordan, S. A., and Palmateer, A. J. 2009. First report of downy mildew caused by a Peronospora sp on basil in Florida and the United States. Plant Dis. 93:199.

Romer, P., Grosch, R., Kofoet, A., and Farahani-Kofoet, R. D. 2010. Selection of basil (Ocimum basilicum) breeding material resistant against downy mildew (Peronospora sp.) and tolerant to low temperature. IV International Symposium on Breeding Research on Medicinal and Aromatic Plants. Isbmap 860:147-152.

Ronco, L., Rollan, C., Choi, Y. J., and Shin, H. D. 2008. Downy mildew of sweet basil (Ocimum basilicum) caused by Peronospora sp. in Argentina. New Dis. Rep. 18:14.

Safrankova, I., and Holkova, L. 2014. The first report of downy mildew caused by Peronospora belbahrii on sweet basil in greenhouses in the Czech Republic. Plant Dis. 98:1579.

Saude, C., Westerveld, S., Filotas, M., and Mcdonald, M. R. 2013. First report and management of basil downy mildew in Ontario. Can. J. Plant Pathol. $35: 123-124$ 
Thines, M., Telle, S., Ploch, S., and Runge, F. 2009. Identity of the downy mildew pathogens of basil, coleus, and sage with implications for quarantine measures. Mycol. Res. 113:532-540.

Voglmayr, H., and Piatek, J. 2008. Peronospora causing downy mildew disease of sweet basil newly reported in Cameroon. New Dis. Rep. 18:37.

Vu, A. L., Daughtrey, M. L., Crouch, J. A., and Wick, R. L. 2013. Comparison of Peronospora species causing downy mildew on basil, coleus, and agastache. (Abstr.) Phytopathology 103(suppl.):S154.

Westerveld, S., Filotas, M., and McDonald, M. R. 2015. First report of downy mildew caused by Peronospora belbahrii on basil (Ocimum spp.) in Ontario. Phytopathology 105:885-894.
Wick, R. L., and Brazee, N. J. 2009. First report of downy mildew caused by a Peronospora species on sweet basil (Ocimum basilicum) in Massachusetts. Plant Dis. 93:318.

Wyenandt, C. A., Simon, J. E., McGrath, M. T., and Ward, D. L. 2010. Susceptibility of basil cultivars and breeding lines to downy mildew (Peronospora belbahrii). HortScience 45:1416-1419.

Wyenandt, C. A., Simon, J. E., Pyne, R. M., Homa, K., McGrath, M. T., Zhang, S. A., Raid, R. N., Ma, L. J., Wick, R., Guo, L., and Madeiras, A. 2015. Basil downy mildew (Peronospora belbahrii): Discoveries and challenges relative to its control. Phytopathology 105:885894. 